https://doi.org/10.22364/hssl.28.1.02

\title{
DIGITALISATION IN REGIONS OF LATVIA - PROBLEMS AND CHALLENGES ${ }^{1}$
}

\section{Biruta Sloka}

Dr. oec.

\section{Kate Čipāne}

M.Sc.

\section{Sabīne Anete Vasina}

M.Sc.

\section{Emīls Volgasts}

\begin{abstract}
Digital skills are defined as a basic competence, the same level as reading or writing and it is important for country to provide successful digitalisation in regions as regional development is the basis for national development.

Purpose of the study is to analyse digitalisation in the regions of Latvia.

The tasks of the study:

1) to analyse theoretical background of digitalisation in context of regional development;

2) to analyse existing research of digitalisation in the regions in EU;

3) to analyse problems of digitalisation in the regions of Latvia.
\end{abstract}

Research methods used in preparation of this article: scientific publication and previous conducted research results analysis, analysis of Digital Economy and Society Index (DESI), EU-SILC results (in 2014-2017) and results of the survey realised in Latvia at the end of 2017 and beginning of 2018 on internet shopping in cooperation with company iMarketing.lv, University of Latvia and Chamber of Trade and Commerce of Latvia $(n=2513)$. Data are compared with the results of other Eurozone and OECD countries. For data analysis there were used indicators of descriptive statistics (indicators of central tendency or location - arithmetic mean, mode, median), indicators of variability (indicators of dispersion - range, standard deviation and standard error of mean), cross-tabulations for regions in Latvia, for household members, for urban - rural living and analysis of variance - ANOVA are

1 The research was supported by the National Research Programme "Latvian Heritage and Future Challenges for the Sustainability of the State" project "Challenges for the Latvian State and Society and the Solutions in International Context (INTERFRAME-LV)". 
used. The results of analysis have indicated different challenges for decision makers on different levels.

Keywords: Latvia, digitalisation, internet, regional development, digital skills gap, digital divide

\section{Introduction}

On June 10, 2016, the European Commission published a new Skills Agenda for Europe where digital skills are defined as a basic competence, the same level as reading or writing. According to the statistics only $58 \%$ of Europeans had basic or above basic digital skills, while in Latvia this level was $48 \%$ in 2017 . Nowadays almost every workplace requires employees to be digitally skilled at least in some level, as most of the operations are carried out using various software and platforms. The technological revolution and further advancements indicate that specialists with digital skills will continue to be highly in demand by the companies worldwide, and this situation creates a large challenge for the labour market in general, as statistics show that there is still room for growth. The situation itself creates a great debate as to whether people can keep up with the pace of how the technologies are being evolved; as currently there is a big rivalry between companies and institutions to employ various information and communication technology (ICT) specialists. According to Eurostat ${ }^{2}$, the number of these specialists in the EU grew by over 39 per cent between the years 2011 and 2018. In 2018, the average rating of the ICT specialists employed in the EU was 3.9\%; the relative share of Finland was $7.2 \%$, but only $1.7 \%$ in Latvia, having the lowest rating among the EU Member states. In March 12, 2019, the World Economic Forum ${ }^{3}$ published an article about the widening digital skills gap as the European Commission stated there could be more than 756 thousand unfilled jobs in the ICT sector by year 2020, and at least 133 million new ICT roles generated globally by 2022 .

Purpose of the current study is to analyse digitalisation in the regions of Latvia.

The tasks of the study:

1) to analyse theoretical background of digitalisation in context of regional development;

2 Eurostat, ICT Specialists by Employment. Available at: https://ec.europa.eu/eurostat/ statistics-explained/index.php/ICT_specialists_in_employment\# Number_of_ICT_ specialists [20.11.2019.]

3 World Economic Forum, The digital skills gap is widening fast. Here's how to bridge it. Available at: https://www.weforum.org/agenda/2019/03/the-digital-skills-gap-is-wideningfast-heres-how-to-bridge-it/ [20.11.2019] 
2) to analyse existing research of digitalisation in the regions in EU;

3) to analyse problems of digitalisation in the regions of Latvia.

Research methods used in preparation of the paper: scientific publication and previous conducted research results analysis, analysis of Digital Economy and Society Index (DESI), EU-SILC results (in 2014-2017) and results of the survey realised in Latvia at the end of 2017 and beginning of 2018 on internet shopping in co-operation with company iMarketing.lv, University of Latvia and Chamber of Trade and Commerce of Latvia $(n=2513)$. Data are compared with the results of other Eurozone and OECD countries. For data analysis there were used indicators of descriptive statistics (indicators of central tendency or location - arithmetic mean, mode, median), indicators of variability (indicators of dispersion range, standard deviation and standard error of mean), cross-tabulations for regions in Latvia, for household members, for urban - rural living and analysis of variance - ANOVA are used.

\section{Digitalisation in regions: theoretical framework}

The presence, absence, and application of digital skills are under research agenda world-wide for different purposes: regarding requirements for students ${ }^{4}$, employment requirements ${ }^{5}$, and for public relations education and practice ${ }^{6}$. The general skills gap has been on research agendas between rural and urban regions. Zarifa et al. ${ }^{7}$ stated that in Canada rural residents acquire lower levels of education than urban residents, due to human capital deficits, as rural regions usually have less opportunities to learning access, as well as urban regions have greater rates of internet access, therefore means easier access to other assets such as information or institutions.

Young $^{-8}$ in his case study in Canada revealed that rural residents in spite of their experience of digital divides are leveraging, reappropriating, and

4 Ukwoma, S., Iwundu, N., Iwundu, I. (2016). Digital literacy skills possessed by students of UNN, implications for effective learning and performance, New Library World, 117(11/12), 702-720.

5 Bokek-Cohen, Y. (2018). Conceptualizing employees' digital skills as signals delivered to employers, International Journal of Organization Theory \& Behaviour, 21(1), 17-27.

6 Cismaru, D., Gazzola, P., Ciochina, R., Leovaridis, C. (2018). The rise of digital intelligence: challenges for public relations education and practices, Kybernetes, 47(10), 1924-1940.

7 Zarifa, D., Seward, B., Milian, R. P. (2019). Location, location, location: Examining the rural-urban skills gap in Canada, Journal of Rural Studies, 72, p. 254.

8 Young, J. C. (2019). Rural digital geographies and new landscapes of social resilience. Journal of Rural Studies, 70, 66-74. 
even creating digital tools to support varied economic landscapes and they also create new sharing economies and provide support of indigenous livelihoods.

Digital skills have been on research agenda for the past years due to technological changes, as well as such terms as "digital skills gap" have become recognised. The term digital skills gap is related to the difference between existing digital skills people possess and needed digital competencies of the workforce to manage technologies. In research, the digital skills gap has been mostly related to certain skills required in the workplace ${ }^{9}$, as there is no surprise that these technologies have a big impact on the way people live and manage their daily routines. As these skills become even more relevant, there has to be a sustainable way to acquire them, e.g., Siddiq et al. ${ }^{10}$ conducted a research in Norway on the impact teachers have on developing students' digital skills and concluded that teachers' classroom practice makes a big impact on how students' digital skills can evolve.

$21^{\text {st }}$ century digital skills are classified as information digital skills, communication digital skills, collaboration digital skills, critical-thinking digital skills, creative digital skills, and problem-solving digital skills ${ }^{11}$. Information digital skills are related to searching, evaluating and managing digital information in various search engines, as well as the ability to digitally manage various forms of digital information (e-mails, files etc.). Information digital skills are considered to be essentially relevant as they are also related to assessment of information credibility regarding information source. Communication digital skills are related to online interactions, as well as sharing content, such as photos, videos, blogs etc. Collaboration digital skills are related to sharing responsibility while performing tasks, but critical-thinking digital skills require the person to be able to make informed judgements about incoming information, as well as assess various sources.

Lastly, creative and problem-solving digital skills are related to online tools that can be used to perform tasks, most often to express one's talent and new ideas, but problem-solving skills are related to conduct researches

9 Oberlander, M., Beinicke, A., Bipp, T. (2020). Digital competencies: A review of the literature and applications in the workplace, Computers \& Education, 146, 103752 , https://doi.org/10.1016/j.compedu.2019.103752

${ }^{10}$ Siddiq, F., Scherer, R., Tondeur, J. (2016). Teachers' emphasis on developing student's digital information and communication skills (TEDDICS): A new construct in $21^{\text {st }}$ century education, Computers \& Educations, 92-93, p. 12.

${ }^{11}$ Laar, E., Deursen, A., Dijk, J., Haan, J. (2019). Determinants of 21st-century digital skills: A large-scale survey among working professionals. Computers in Human Behaviour, 100, p. 94 . 
and gather information on certain subjects to make informed decisions. Use of digital education resources in schools of rural areas has been researched in China ${ }^{12}$, as well as access to the Internet has shown a big impact on acquisition of digital skills, e.g., in a remote and rural geography ${ }^{13}$ the Internet is slower, more unreliable and expensive, therefore people use it less and are separated from the digital space, forming a digital divide. The terms digital divide, digital exclusion and digital inequality have been addressed before in research, and are strongly related to high proficiency of these skills or lack thereof. The digital divide is formed when there are inequalities in access to and use of Information and Communication Technologies (ICT's). Philip ${ }^{14}$ et al. have considered that relatively little amount of research has been done to analyse rural perspectives on digital challenges. From their analysis on the urban-rural digital divide in Great Britain, researchers found out that there are territorial inequalities in digital infrastructure which negatively impacts life in rural areas of Britain.

In research papers one of the most important determinants of digital divide is access to the Internet and Internet use, although Scheerder et al. ${ }^{15}$ have stated that there is not enough research conducted on the Internet skills, as well as the third-level digital divide, a situation in which digital skills and use of the Internet do not lead to beneficial outcomes.

There have been various approaches to assess the digital divide, e.g. it has been researched in education across and within the EU-28 countries according to the educational attainment, particularly analysing internal gaps which in other cases would have been overlooked, ${ }^{16}$ as well as gender digital divide has been researched to address the digital literacy skills between women and men. ${ }^{17}$ When exploring the individual ability to use

${ }^{12}$ Wang, J., Tigelaar, D., Admiraal, W. (2019). Connecting rural schools to quality education: Rural teachers' use of digital educational resources, Computers in Human Behaviour, 101, p. 71.

${ }^{13}$ Young, J. C. (2019). Rural digital geographies and new landscapes of social resilience, Journal of Rural Studies, 70, p. 72.

${ }^{14}$ Philip, L., Cottrill, C., Farrington, J., Williams, F., Ashmore, F. (2017). The digital divide: Patterns, policy and scenarios for connecting the final few in rural communities across Great Britain, Journal of Rural Studies, 54, p. 387.

${ }^{15}$ Scheerder, A., Deursen, A., Dijk, J. (2017). Determinants of Internet skills, uses and outcomes. A systematic review of the second-and third-level digital divide, Telematics and Informatics, 34, p. 1614.

${ }^{16}$ Jesus, F., Vicente, M., Bacao, F., Oliviera, T. (2016). The education-related digital divide: An analysis for the EU-28, Computers in Human Behaviour, 56, 72-82.

${ }^{17}$ Mumporeze, N., Prieler, M. (2017). Gender digital divide in Rwanda: A qualitative analysis of socioeconomic factors, Telematics and Informatics, 34, 1285-1293. 
the benefits the Internet provides, researchers Blank and his colleagues ${ }^{18}$ have suggested that there has been a shift of focus from digital divides to digital inequalities - such an aspect is of great importance in many countries including Latvia. The determinants showing this focus are as follows: digital skills and literacy, the autonomy of users when accessing the Internet, the social support available to those wanting to use the Internet, and the extent to which the individuals are integrated into so-called "techno-culture".

\section{Empirical research results}

In order to get a broader view of the challenges and problems of digitalization, different data sourced were used in this research - Digital Society and Economy index (DESI), The European Union Statistics on Income and Living Conditions (EU-SILC) and survey "Shopping Habits in the Internet in 2017 in Latvia”.

Digital Society and Economy index (DESI) is a composite index that summarises some 30 relevant indicators on Europe's digital performance and tracks the evolution of EU Member States, across five main dimensions: Connectivity, Human Capital, Use of Internet, Integration of Digital Technology, Digital Public Services (Eurostat, 2019).

EU-SILC is the most complete harmonised survey on household income in Europe. EU-SILC survey is conducted annually in line with Eurostat methodology in all European Union countries. In order to acquire information four questionnaires were developed: Household Register, Household Questionnaire Form and Individual Questionnaire Form.

One of the main study objects of the EU-SILC is annual income of a household - their composition and level, in the 2017 sample size of the EU-SILC in the Republic of Latvia - 8087 randomly selected respondents; Completed questionnaire sets were of 6014 households; individual interviews (persons) - 11 304; non-response rate of EU-SILC in Latvia was 25.6\% (CSB of Republic of Latvia, 2019).

It is important that anonymised data sets are available in SPSS files for more detailed statistical data analysis - by statistical regions, by territories (cities or rural areas), by household size and by other indicators.

The survey "Shopping Habits in the Internet in 2017" was realised at the end of 2017 and beginning of 2018 in Latvia in co-operation with company iMarketing, University of Latvia and Chamber of Trade and Commerce of Latvia. The survey was located on one of the most popular internet 
platforms in Latvia inbox.lv $v^{19}$ and randomly selected possible respondents were invited to fill the survey. It was ensured that each respondent can fill the survey only once. All data of the survey were obtained in SPSS to provide deep data analysis using indicators of descriptive statistics (arithmetic mean, mode, median, variance etc.), cross-tabulations, testing of statistical hypotheses and correlation analysis.

The sample of the survey consisted of 2513 responses. In Table 1 is included detailed information the demographic characteristics of the sample.

Table 1. Demographic characteristics of the respondents in survey on internet shopping in Latvia

\begin{tabular}{|c|c|c|c|}
\hline & & $\mathbf{N}$ & Percent \\
\hline \multirow{2}{*}{ Gender } & Female & 878 & 62,9 \\
\hline & Male & 518 & 37.1 \\
\hline \multirow{7}{*}{ Age } & Under 18 & 26 & 1.8 \\
\hline & $18-24$ & 135 & 9.6 \\
\hline & $25-34$ & 357 & 25.3 \\
\hline & $35-44$ & 369 & 26.2 \\
\hline & $45-54$ & 324 & 23.0 \\
\hline & $55-64$ & 157 & 11.1 \\
\hline & $65+$ & 41 & 2.9 \\
\hline \multirow{5}{*}{ Region } & Riga and the region of Riga & 676 & 48.0 \\
\hline & Kurzeme district & 222 & 15.8 \\
\hline & Latgale district & 148 & 10.5 \\
\hline & Vidzeme district & 214 & 15.2 \\
\hline & Zemgale district & 147 & 10.4 \\
\hline \multirow{5}{*}{$\begin{array}{l}\text { The last time of purchase } \\
\text { or order of a product or } \\
\text { service online }\end{array}$} & Over the last 30 days & 1343 & 63.4 \\
\hline & \begin{tabular}{|l|} 
Two months ago \\
\end{tabular} & 281 & 13.3 \\
\hline & Three months ago & 108 & 5.1 \\
\hline & Six months ago & 113 & 5.3 \\
\hline & I do not remember & 273 & 12.9 \\
\hline
\end{tabular}

Source: Authors calculations based on the survey in 2018, $n=2513$

The sample of the survey consisted more of female respondents than male. The most represented age group was from 35 to 44 years $(26.2 \%)$,

${ }^{19}$ TOP 20 websites in February 2019 (in Latvia), Gemius. Available at: https://www. gemius.lv/all-reader-news/gemius-publice-interneta-lapu-top-20-februari-2019.html [viewed 30.03.2019.] 
however also respondents from 25 to 34 years (25.3\%) and from 45 to 54 years $(23 \%)$ were represented properly. The least represented groups were under 18 years old (1.8\%) and over 65 years old (2.9). Almost half of the respondents were from Riga or Riga region (48\%), but the remaining respondents were evenly distributed in the other regions of Latvia. Most of the respondents had been shopping online in the last six month and only $12.9 \%$ did not remembered the last time shopping online, but what is important - all respondents have been shopping online.

\section{Digitalisation in the regions in $\mathrm{EU}$}

Since 2010, Digital Agenda for Europe aims to stimulate the European economy by ensuring that the digital single market delivers sustainable economic and social benefits as this digital economy is growing faster than any other industry ${ }^{20}$. Digital Economy and Society index is a composite index that summarises relevant indicators on Europe's digital performance and tracks the evolution of EU member states in digital competitiveness since 2014. ${ }^{21}$ This index consists of five dimensions - connectivity, human capital, use of internet, integration of digital technology and digital public services. In 2019, in the connectivity dimension, Denmark has the highest score, followed by Luxembourg, the Netherlands, Sweden and Finland, but Greece, Croatia and Lithuania had the weakest performance in this dimension. In the Human capital dimension, Finland, Sweden, Luxembourg and Estonia obtained the highest scores. Bulgaria, Romania, Italy and Greece had the lowest ones. There are still large disparities across EU regarding the third dimension - use of internet. Denmark, the Netherlands, Sweden and Finland have the most active internet users, followed by the UK, Luxembourg, Estonia and Malta. Romania, Bulgaria and Greece are, by comparison, the least active. On Integration of digital technology, Ireland scored highest, followed by the Netherlands, Belgium and Denmark. In digital public services, Finland has the highest score, followed by Estonia, the Netherlands and Spain. More detailed results of Digital Economy and Society Index in European Union countries in 2019 are included in Figure 1. 


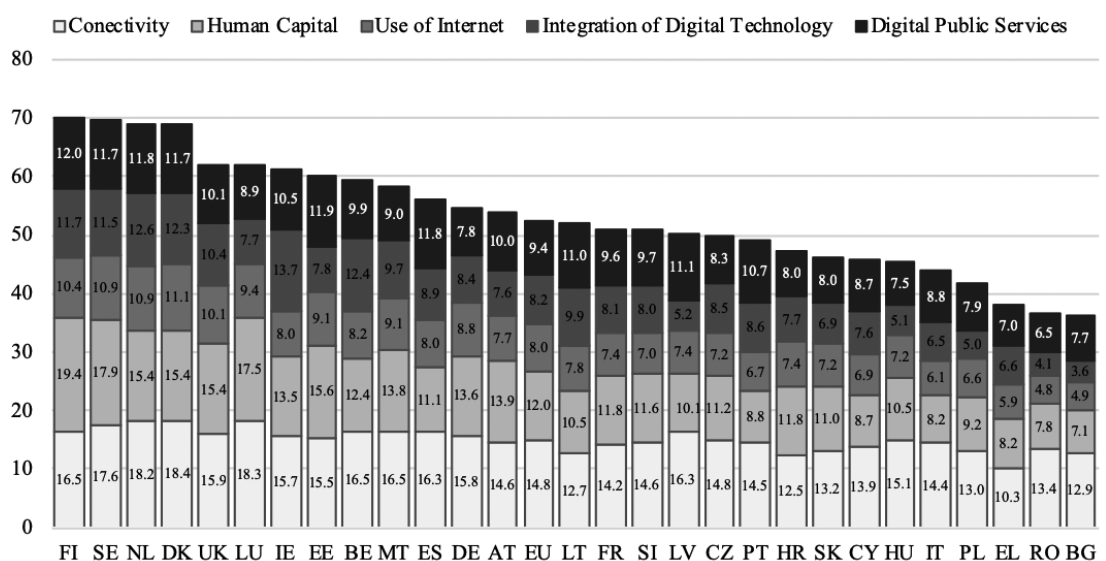

Figure 1. Digital Economy and Society Index in EU in 2018

Source: Authors construction based on data bases of Eurostat

The statistics shows that Finland, Sweden, the Netherlands and Denmark have the most advanced digital economies in the EU followed by the UK, Luxembourg, Ireland and Estonia. Bulgaria, Romania, Greece and Poland have the lowest scores on the index. Latvia is below average level of European Union, while Lithuania is above Latvia and still below EU average, but Estonia is far above the average level of EU. The connectivity dimension measures the deployment of broadband infrastructure (fixed broadband, mobile broadband) and its quality, access to fast and ultrafast broadband and prices. The situation in Latvia is at the same level as in Finland, Montenegro and Spain, and Latvia is in better position in connectivity than Lithuania and Estonia. The second dimension - human capital - measures the skills needed to take advantage of the possibilities offered by digital and Latvia is in relatively bad position comparing to Finland, Sweden, Luxembourg and even Estonia while Lithuania is in the same level; this data shows that internet user skills should be improved in Latvia. The third dimension is Use of Internet which accounts for a variety of online activities, such as the consumption of the online content (videos, music, games, etc.) video calls, as well as online shopping and banking. Also, in this dimension Latvia is below the EU average level and in the same level as France, Czech Republic and Croatia. The fourth is Integration of digital technology dimension, which measures the digitalisation of businesses and e-commerce. By adopting digital technologies, businesses can enhance efficiency, reduce costs and better engage customers and business partners. Furthermore, Internet as a sales outlet offers access to wider markets and potential for growth. 
In this dimension Latvia is in one of the lowest levels in European Union followed only by Poland, Romania and Bulgaria while the situation in Lithuania is better than in Estonia. The last and fifth dimension Digital public services measure the digitalisation of public services, focusing on e-Government and e-Health where Latvia is above EU average level and is almost in the same level as Finland, Sweden, Netherlands, Denmark and Estonia. From these five dimensions Connectivity and Digital public services dimension are above EU average level, while such dimensions as Human Capital, Use of Internet and Integration of Digital Technology especially should be improved in following years.

\section{Problems and challenges of digitalisation: the Case of Latvia}

As Digital Economy and Society Index reflects that situation in Latvia is critical in such dimensions as Human Capital, Use of Internet and Integration of Digital Technology, the following research is devoted to indicate challenges and problems of these dimensions in detail in regions of Latvia.

The Central Statistical Bureau of Latvia has compiled a variety of e-skills in regions of Latvia, which are revealed in Table 2.

Table 2. E-skills in Regions in Latvia in 2017, \%

\begin{tabular}{|c|c|c|c|c|c|c|c|c|c|c|}
\hline & 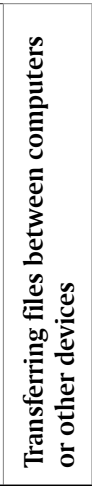 & 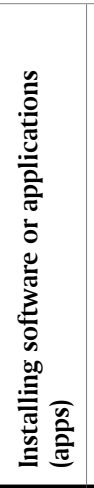 & 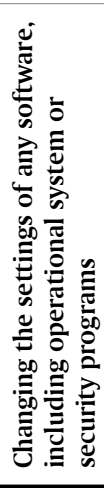 & 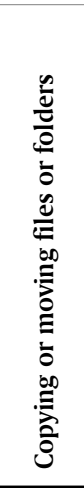 & 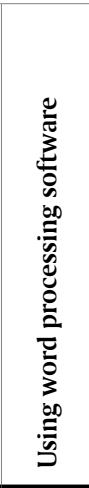 & 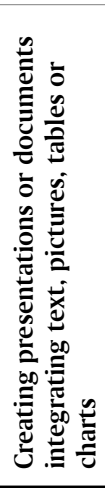 & 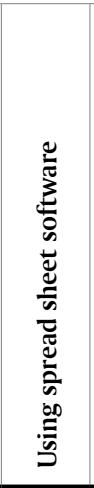 & 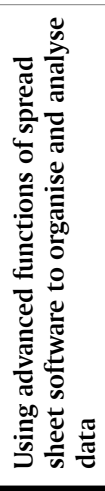 & 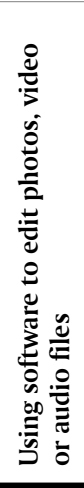 & 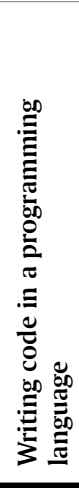 \\
\hline Rīga & 71.50 & 40.30 & 20.70 & 70.40 & 52.60 & 27.40 & 39.90 & & 18.60 & 3.10 \\
\hline Pierīga & 66.40 & 34.10 & 16.70 & 66.30 & 42.80 & 24.80 & 32.30 & 21.40 & 14.40 & 1.80 \\
\hline Vidzeme & 61.40 & $29.30^{0}:$ & 11.10 & 61.00 & 39.70 & 25.30 & 24.80 & 17.00 & 13.30 & 1.50 \\
\hline Kurzeme & 66.50 & 27.90 & 15.90 & 68.10 & 41.00 & 20.40 & 30.70 & 20.80 & 16.70 & 1.60 \\
\hline Zemgale & 65.70 & 26.80 & 12.40 & 580 & 28.70 & 19.20 & 18.80 & & 12.50 & 1.20 \\
\hline Latgale & & & 14.80 & & & & & & & \\
\hline
\end{tabular}

Source: Authors construction based on data bases of CSB, Republic of Latvia 
The statistics show that the best e-skills in all categories are in the Riga region, followed by the Pierīga region. The lowest level of such e-skills as transferring files between computers or other devices, installing software or applications, copying or moving files or folders, using advanced functions of spread sheet software to organise and analyse data, using software to edit photos, video or audio files and writing code in a programming language is in Latgale region, while very bad skills of changing the settings of any software, including operational system or security programs are in Vidzeme region, but such e-skills as using word processing software, creating presentations or documents integrating text, pictures, tables or charts and using spread sheet software should be improved in Zemgale region.

According to the administrative breakdown, there are 6 regions in Latvia: Rīga, Pierīga, Vidzeme, Kurzeme, Zemgale and Latgale. Regional development is on great importance, because regions are developing unevenly in Latvia. Rīga and Pierīga region are developed better than the others, for example, Latgale region, which is facing serious economic development problems. Internet use by individuals in the regions of Latvia is revealed in Figure 2.

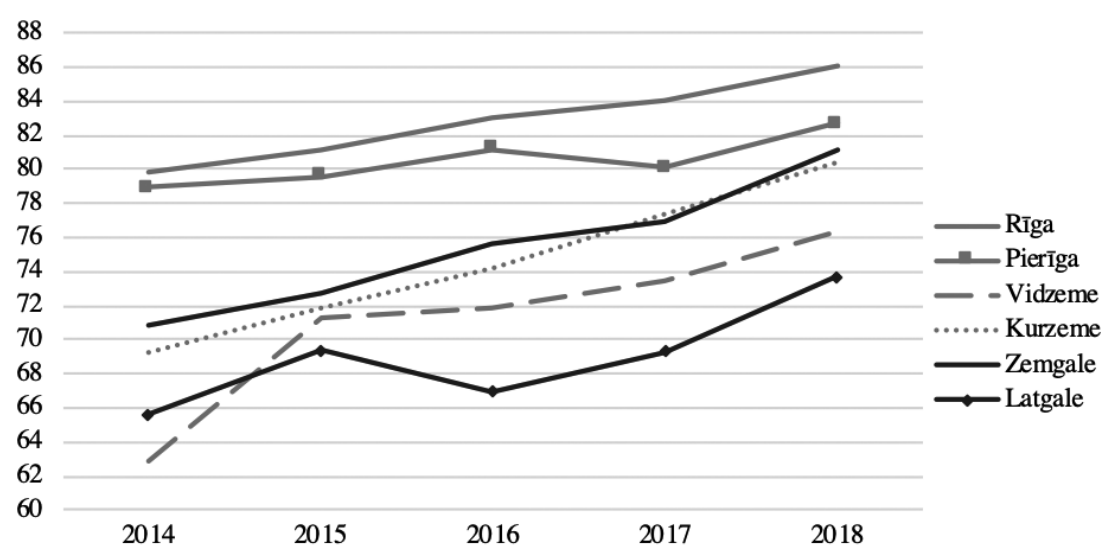

Figure 2. Internet use by individuals in regions of Latvia (\%) in 2014-2017

Source: Authors construction based on data bases of CSB

Data included in Figure 2 show that internet use by individuals has been growing since 2014 in all regions in Latvia. The best situation is in the capital of Latvia - Riga region - where internet use by individuals has been growing constantly since 2014. The second region more active region's inhabitants by internet use by individuals is Pierīga region 
(the region around the capital of Latvia) where a decrease was observed only in 2017, but after that - an increase in 2018. Zemgale and Vidzeme region have experienced the fastest growth on Internet use since 2014, followed by Vidzeme region, but of special concern is about the Latgale region where the share of inhabitants on internet use by individuals is increasing, however, it is the lowest in the country.

The survey "Shopping habits on the Internet in 2017" has been researching reasons on internet use in Latvia and the main statistical indicators on respondent's evaluations on use of the Internet are included in Table 3.

Table 3. Main statistical indicators on respondent's evaluations on use of Internet in Latvia at the end of 2018

\begin{tabular}{|c|c|c|c|c|c|c|c|c|c|}
\hline $\begin{array}{l}\text { Statistical } \\
\text { indicators }\end{array}$ & Work & $\begin{array}{l}\text { Shop- } \\
\text { ping }\end{array}$ & $\begin{array}{c}\text { Use of } \\
\text { Social } \\
\text { Networks }\end{array}$ & $\begin{array}{l}\text { Commu- } \\
\text { nication } \\
\text { with } \\
\text { friends, } \\
\text { relatives }\end{array}$ & $\begin{array}{l}\text { Read } \\
\text { News }\end{array}$ & $\begin{array}{l}\text { Search } \\
\text { Infor- } \\
\text { mation }\end{array}$ & $\begin{array}{c}\text { Check } \\
\text { e - } \\
\text { mail }\end{array}$ & $\begin{array}{l}\text { Watch } \\
\text { Video }\end{array}$ & $\begin{array}{c}\text { Manage } \\
\text { pay- } \\
\text { ments }\end{array}$ \\
\hline Valid & 2166 & 2166 & 2166 & 2166 & 2166 & 2166 & 2166 & 2166 & 2166 \\
\hline Missing & 0 & 0 & 0 & 0 & 0 & 0 & 0 & 0 & 0 \\
\hline Mean & 7.16 & 6.86 & 8.47 & 7.91 & 7.76 & 8.83 & 8.76 & 7.70 & 8.62 \\
\hline $\begin{array}{l}\text { Std. Error } \\
\text { of Mean }\end{array}$ & 0.069 & 0.059 & 0.053 & 0.056 & 0.055 & 0.043 & 0.049 & 0.056 & 0.056 \\
\hline Median & 8 & 7 & 10 & 9 & 9 & 10 & 10 & 9 & 10 \\
\hline Mode & 10 & 10 & 10 & 10 & 10 & 10 & 10 & 10 & 10 \\
\hline $\begin{array}{l}\text { Std. } \\
\text { Deviation }\end{array}$ & 3.210 & 2.739 & 2.449 & 2.597 & 2.547 & 1.996 & 2.285 & 2.590 & 2.619 \\
\hline Variance & 10.302 & 7.503 & 5.997 & 6.746 & 6.485 & 3.984 & 5.220 & 6.707 & 6.857 \\
\hline Range & 9 & 9 & 9 & 9 & 9 & 9 & 9 & 9 & 9 \\
\hline Minimum & 1 & 1 & 1 & 1 & 1 & 1 & 1 & 1 & 1 \\
\hline Maximum & 10 & 10 & 10 & 10 & 10 & 10 & 10 & 10 & 10 \\
\hline
\end{tabular}

Evaluation scale 1 - 10 , where 1 - do not use; 10 - use very often Source: Authors calculations based on survey in 2018, $n=2166$

The results of the survey analysis indicate that most of respondents use internet, firstly, for searching information with rather large average evaluations (arithmetic mean, mode and median) by respondents and the smallest variability indicated by standard deviation and other indicators of variability, secondly, for checking e-mail with rather large average 
evaluations (arithmetic mean, mode and median) by respondents and the rather small variability indicated by standard deviation and other indicators of variability and, thirdly, for managing payments. Respondents had different views as all evaluation scales 1-10 was used by respondents of the survey.

The lowest evaluations were on internet use in Latvia was used for shopping, which is different from many other developed countries. As this aspect is important in Digital Economy and Society Index and should be a seriously studied aspect as to why inhabitants in Latvia are so inactive on the use of internet for shopping - what are the main reasons of their concerns and what conditions have to be improved to be on the same wave as the developed world.

Distribution of responses on respondent's evaluations on the use of the Internet for shopping in Latvia is included in Table 4 where it is seen that rather big share of inhabitants in Latvia do not use Internet for shopping of use it very seldom.

Table 4. Distribution of responses on respondent's evaluations on use of Internet for Shopping in Latvia in 2017

\begin{tabular}{|c|c|c|c|c|}
\hline Evaluations & Frequency & Percent & Valid Percent & Cumulative Percent \\
\hline 1 & 108 & 5.0 & 5.0 & 5.0 \\
\hline 2 & 80 & 3.7 & 3.7 & 8.7 \\
\hline 3 & 115 & 5.3 & 5.3 & 14.0 \\
\hline 4 & 111 & 5.1 & 5.1 & 19.1 \\
\hline 5 & 319 & 14.7 & 14.7 & 33.8 \\
\hline 6 & 168 & 7.8 & 7.8 & 41.6 \\
\hline 7 & 236 & 10.9 & 10.9 & 52.5 \\
\hline 8 & 285 & 13.2 & 13.2 & 65.7 \\
\hline 9 & 173 & 8.0 & 8.0 & 73.6 \\
\hline 10 & 571 & 26.4 & 26.4 & 100.0 \\
\hline Total & 2166 & 100.0 & 100.0 & \\
\hline
\end{tabular}

Evaluation scale 1 - 10, where 1 - do not use; 10 - use very often Source: Authors calculations based on survey in 2018, $n=2166$

As the data included in Table 4 indicate that $5 \%$ of respondents do not use internet for shopping, but half of respondents gave an evaluation of 7 or less affirming that online shopping is not the primary activity consumers do online. 
To better understand the situation households of Latvia are in the authors highlight not only reasons why people choose to use the internet, but also why people choose not to have access to the internet. The Central Statistical Bureau of Latvia has held a survey that allows identifying the main reasons why households choose not to have access to the Internet at home (Table 5).

Table 5. Reasons for not having access to the Internet at home at the beginning of 2019, \% of households in Latvia

\begin{tabular}{|l|c|c|c|c|c|c|c|c|}
\hline & $\begin{array}{c}\text { Have } \\
\text { access to } \\
\text { Internet } \\
\text { elsewhere }\end{array}$ & $\begin{array}{c}\text { Don't } \\
\text { need } \\
\text { Internet }\end{array}$ & $\begin{array}{c}\text { Equipment } \\
\text { costs too } \\
\text { high }\end{array}$ & $\begin{array}{c}\text { Access } \\
\text { costs } \\
\text { too } \\
\text { high }\end{array}$ & $\begin{array}{c}\text { Lack } \\
\text { of } \\
\text { skills }\end{array}$ & $\begin{array}{c}\text { Privacy or } \\
\text { security } \\
\text { concerns }\end{array}$ & $\begin{array}{c}\text { Broadband } \\
\text { internet } \\
\text { is not } \\
\text { available in } \\
\text { our area }\end{array}$ & Other \\
\hline $\begin{array}{l}\text { Riga } \\
\text { region }\end{array}$ & 1.3 & 6.7 & 1.9 & 1.4 & 2.6 & 0.3 & 0.0 & 2.6 \\
\hline $\begin{array}{l}\text { Pierīga } \\
\text { region }\end{array}$ & 2.6 & 9.3 & 1.7 & 1.7 & 4.8 & 0.1 & 0.0 & 4.8 \\
\hline $\begin{array}{l}\text { Vidzeme } \\
\text { region }\end{array}$ & 3.4 & 9.6 & 6.7 & 4.9 & 7.2 & 0.0 & 0.1 & 7.2 \\
\hline $\begin{array}{l}\text { Kurzeme } \\
\text { region }\end{array}$ & 1.4 & 10.2 & 2.9 & 2.1 & 6.5 & 1.1 & 0.5 & 6.5 \\
\hline $\begin{array}{l}\text { Zemgale } \\
\text { region }\end{array}$ & 1.9 & 6.7 & 6.0 & 5.2 & 8.4 & 1.3 & 0.7 & 8.4 \\
\hline $\begin{array}{l}\text { Latgale } \\
\text { region }\end{array}$ & 2.0 & 14.4 & 6.5 & 4.5 & 6.9 & 0.2 & 0.6 & 6.9 \\
\hline
\end{tabular}

Source: Central Statistical Bureau of Latvia

Data included in table 5 clearly state that the main reason for not having internet access at households is the inability to recognise its use and the value it could bring to the household. On average 9.5 percent of households have chosen that they don't need internet access. As the second greatest reason averaging 6.1 percent of households is lack of skills. And only the third greatest reason averaging 4.3 percent of households is high equipment costs.

The authors highlight that data of table 5 is another proof that the situations in different regions are not the same. Therefore, to solve the issues related to digitalization and sustain steady and equal digitalization it would be best to use a personalised approach to each region - in such a way addressing the greatest obstacles and opportunities of digitization in each region. 


\section{Conclusions}

1. Digitalisation and development of digitalisation skills is becoming more and more important to be competitive and to survive in digitalised world. It makes for numerous topics for academic research world-wide.

2. Application of digitalisation skills is very different in many countries, also in Latvia there are differences in Internet use in regions in Latvia.

3. Among all five dimensions in Digital Economy and Society Index Latvia scores best in e-government as well as in connectivity - Latvia is well equipped with very high-speed fixed network infrastructure, has near-complete $4 \mathrm{G}$ coverage of households, and is prepared for $5 \mathrm{G}$ deployment. Digital skills in Latvia needs to be seriously improved as they are below EU average and without relevant progress. Higher level of digital skills is needed to make the national labour market more inclusive and to improve business productivity, because on Integration of digital technology dimension Latvia ranks 24th among EU countries. It is important to raise awareness of importance of digitalization in small and medium enterprises as there is a big potential for e-commerce in Latvia.

4. E-skills in regions of Latvia are very different - the best e-skills are in Rīga and Pierīga region, while low level of e-skills is in Latgale and Zemgale region. Public administrators could suggest different e-skills improvement possibilities and manage joint work of education providers on offering life-long education programs for e-skills improvement.

5. In 2019, three main reasons for not having internet access at households in Latvia are no need for internet, lack of skills and high equipment costs. Each of which would require different solutions to be improved.

6. Different regions are not the same in their level of digitalization, and most important aspects of digitalization vary in each region. To address the greatest obstacles and opportunities of digitalization in each region it would best to use a personalised approach in targeting each region.

\section{REFERENCES}

Blank, G., Groselj, D. (2015). Examining Internet use through a Weberian lens, International Journal of Communication, 9, 2763-2783.

Bokek-Cohen, Y. (2018). Conceptualizing employees' digital skills as signals delivered to employers, International Journal of Organization Theory \& Behaviour, 21(1), 17-27.

Cismaru, D., Gazzola, P., Ciochina, R., Leovaridis, C. (2018). The rise of digital intelligence: challenges for public relations education and practices, Kybernetes, 47(10), 1924-1940. 
Eurostat, (2019). ICT Specialists by Employment. Available at: https://ec.europa. eu/eurostat/statistics-explained/index.php/ICT_specialists_in_employment\# Number_of_ICT_specialists [Accessed 20.11.2019.]

Jesus, F., Vicente, M., Bacao, F., Oliviera, T. (2016). The education-related digital divide: An analysis for the EU-28, Computers in Human Behaviour, 56, 72-82.

Laar, E., Deursen, A., Dijk, J., Haan, J. (2019). Determinants of 21st-century digital skills: A large-scale survey among working professionals. Computers in Human Behaviour, 100, 93-104.

Mumporeze, N., Prieler, M. (2017). Gender digital divide in Rwanda: A qualitative analysis of socioeconomic factors, Telematics and Informatics, 34, 1285-1293.

Oberlander, M., Beinicke, A., Bipp, T. (2020). Digital competencies: A review of the literature and applications in the workplace, Computers \& Education, 146, 103752, https://doi.org/10.1016/j.compedu.2019.103752

Philip, L., Cottrill, C., Farrington, J., Williams, F., Ashmore, F. (2017). The digital divide: Patterns, policy and scenarios for connecting the final few in rural communities across Great Britain, Journal of Rural Studies, 54, 386-398.

Scheerder, A., Deursen, A., Dijk, J. (2017). Determinants of Internet skills, uses and outcomes. A systematic review of the second-and third-level digital divide, Telematics and Informatics, 34, 1607-1624.

Siddiq, F., Scherer, R., Tondeur, J. (2016). Teachers' emphasis on developing student's digital information and communication skills (TEDDICS): A new construct in $21^{\text {st }}$ century education, Computers $\mathcal{E}$ Educations, 92-93, 1-14.

TOP 20 websites in August 2019, Gemius. Available at: https://www.gemius.lv/ reklamdeveji-zinas/gemius-publice-interneta-lapu-top-20-augusta-topampievienojas-santalv.html [Accessed 20.11.2019.]

Ukwoma, S., Iwundu, N., Iwundu, I. (2016). Digital literacy skills possessed by students of UNN, implications for effective learning and performance, New Library World, 117(11/12), 702-720.

Wang, J., Tigelaar, D., Admiraal, W. (2019). Connecting rural schools to quality education: Rural teachers' use of digital educational resources, Computers in Human Behaviour, 101, 68-76.

World Economic Forum, (2019). The digital skills gap is widening fast. Here's how to bridge it. Available at: https:/www.weforum.org/agenda/2019/03/the-digital-skillsgap-is-widening-fast-heres-how-to-bridge-it/ [Accessed 20.11.2019.]

Young, J. C. (2019). Rural digital geographies and new landscapes of social resilience. Journal of Rural Studies, 70, 66-74.

Zarifa, D., Seward, B., Milian, R. P. (2019). Location, location, location: Examining the rural-urban skills gap in Canada, Journal of Rural Studies, 72, 252-263. 